\title{
Species diversity of Spiders (Araneae) in Mimbilisan Pro- tected Landscape, Misamis Oriental, Philippines
}

\author{
Inamol Hassan G. Lucman', Olga M. Nuñeza'* \& Aimee Lynn B. Dupo² \\ ${ }^{1}$ Department of Biological Sciences, College of Science and Mathematics and Premier Research Institute of Science and Mathe- \\ matics, MSU-Iligan Institute of Technology, Iligan City, Philippines. \\ ${ }^{2}$ Department of Biology, University of the Philippines, Los Banos, Museum of Natural History, Pedro R. Sandoval Ave, Los Baños, \\ Laguna, Philippines. \\ ${ }^{*}$ Corresponding author, email: olgamnuneza@yahoo.com
}

\begin{abstract}
Spiders have a potential role as bioindicator of ecological health. Yet, little is known about them especially in forested areas of the Philippines. This study determined the species diversity of spiders in three different sampling sites established in Mt. Mimbilisan Protected Landscape. A combination of beat-netting and vial-tapping methods was used to collect samples. One hundred eight species of spiders belonging to 17 families were recorded. Fifteen species are a new record to the Philippines. Highest species richness and abundance were observed in the riparian forest (Site 2) and lowest in the mixed dipterocarp forest (Site 1). Salticidae is the spider family with the highest species richness and abundance. Opadometa fastigata of family Tetragnithidae was the most abundant species. A great number of adult spiders $(82.42 \%)$, which were mostly females $(88.00 \%)$, was documented. Even distribution $(E=0.7676)$ was recorded in the whole study area. Leaf surfaces and branches or stem of plants were the most recurring microhabitat types of spiders. The spiders were found to belong to seven guilds with the orb weavers as the most dominant guild (37\%). The highest diversity was recorded in Site $2\left(\mathrm{H}^{\prime}=3.781\right)$. Results indicate high spider diversity in Mt. Mimbilisan which highlights the conservation importance of the protected landscape.
\end{abstract}

KEY WORDS Araneidae; conservation; forest; orb-weavers; Salticidae.

Received 12.03.2020; accepted 20.05.2020; published online 30.06.2020

\section{INTRODUCTION}

Spiders belong to a special group of invertebrates comprising the largest order Araneae. They are sensitive to environmental changes and influence neighboring populations. They are abundant and diverse in nature (Wilder, 2011). They encompass the class Arachnida that utilizes a wide range of niches (Puja, 2014). Spiders are a mega-diverse group comprising 47,445 described species (World Spider Catalog, 2018) and are considered as the seventh most diverse order worldwide (Cardoso,
2012). They can be found all around except in air and water (Foelix, 2011), from trees, under stones and logs, in garbage, and on the forest floor (Mathew et al., 2009).

Spiders are considered as an important group from both an economic standpoint in their use as biological control agent and in their diversity and adaptation to a number of differing habitats (Mahalakshmi \& Jeyaparuathi, 2014). They respond rapidly to alterations in environment and thus, used as indicators of ecological change (Hodge \& Vink, 2010). They serve as limiting factors in the increase 
of pest populations in different ecosystems through their predatory behavior (Sharma, 2014). Spider silk nowadays is used to make bullet proof vest, parachutes, surgical threads, artificial tendons, and even biodegradable bottles (Hinman et al., 2003). Venom of spiders is being studied in the field of medicine (Clarke, 2002).

According to Chen \& Tso (2004), a lot of scientific studies on spiders were conducted in temperate regions while tropical areas have relatively less investigation. Species richness and their relative abundance help in describing spider communities (Sorensen et al., 2002). Without being affected by their high diversity and ubiquity, large quantities of species have restricted distribution and biogeographic patterns of assemblages (Carvalho et al., 2011). Royauté \& Buddle (2012) reported that in agricultural fields, there are evidences that synchronization with habitat changes and disturbances are present in species that are dominant. Areas near or with human settlements in Brazil have higher spider diversity indices and evenness values when compared to undisturbed areas (Freitas et al., 2013). Environment alterations may affect their distribution and assemblages by variations of plant community structure, disturbance, and abiotic factors (Juario et al., 2016). According to Hore \& Uniyal (2009), spiders are utilized as bioindicators for evaluating the impact of anthropogenic disturbances on natural ecosystems. They face an exceptionally high risk of extinction (Thomas et al., 2004) caused by human disturbance and climate change.

The Philippines, a tropical country, is among the 17 mega diverse countries which constitutes 70$80 \%$ of the world's biodiversity. For many parts of the Philippines, little is known of the arthropod fauna. One of the most diverse groups of organisms in the Philippines is the spiders (Wankhade et al., 2012) consisting of about 517 species belonging to 225 genera and 38 families. Studies on spiders in the country are limited only to agricultural areas, particularly rice fields, but they have the highest record in all of Asia's tropical rice fields (Workman, 1896; Barrion \& Litsinger, 1995; Barrion, 2001). In Mindanao, the second largest island in the Philippines, recent studies on spiders were reported in $\mathrm{Pu}-$ lacan falls, Zamboanga del Sur (Dacanay et al., 2014), Mt. Matutum, South Cotabato (Garciano et al., 2014), Mt. Pinukis, Zamboanga del Sur (Lalisan et al., 2015), Marilog District, Davao City (Patiño et al., 2016), Sacred Mountain in Marawi City (Juario et al., 2016), Imbayao, Bukidnon (Mondejar \& Nuñeza, 2016), and caves in Mindanao (Enriquez \& Nuñeza, 2014).

Of the remaining forest in the country, $26 \%$ can only be found in protected areas (Ong, 2002). Mimbilisan Protected Landscape is among the 240 protected landscape areas of the Philippines. However, there is no spider fauna data in this protected landscape and thus, this research is significant as this will provide baseline data of spider fauna and will indicate the present ecological health status of Mimbilisan Protected Landscape. It will also contribute to the existing studies on spiders in the Philippines especially on the island of Mindanao. The study aimed to determine species diversity, guild structure, and microhabitats of spiders in Mimbilisan Protected Landscape.

\section{MATERIAL AND METHODS}

\section{Study area}

Based on the IUCN Protected Area Management Category System, Mimbilisan Protected Landscape (Figs. 1-3) belongs to Category 5, areas that are managed for landscape conservation or recreation. It serves as a watershed that provides water to its nearby communities. It is composed of mixed dipterocarp forest that covers 66.515 hectares in Brgy. Mapua, municipality of Balingaoan, Misamis Oriental. Mimbilisan Protected Landscape is located at 8.94617 latitude; 124.8676 longitude. The Mindocdocan Creek can be found at its base. In some areas outside of the protected area, agricultural activity was observed.

\section{Sampling sites}

Three sites in Mimbilisan Protected Landscape were sampled for 10 days for a total of 186 work hours. The sampling sites were selected based on the following criteria: accessibility, habitat structure, degree of exposure to human activities, and geographical position. Disturbances in the sampling sites were qualitatively categorized as low, intermediate, or high based on the accessibility, presence of facilities, and presence of human dis- 


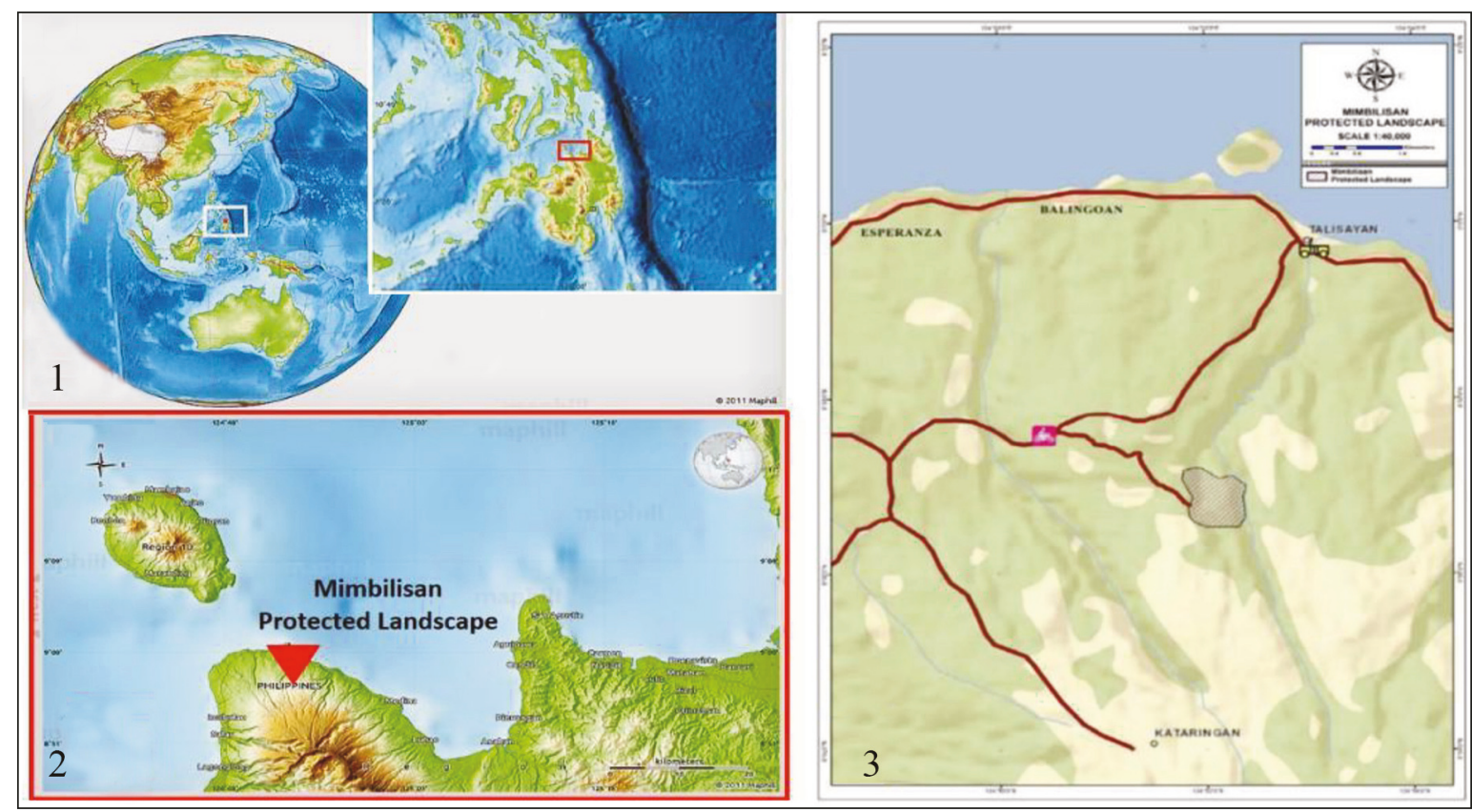

Figure 1. Map of Australasia and central-southern Philippines (Maphill, 2018). Figure 2. Map of northern Mindanao (Maphill, 2018). Figure 3. Location of the study area (BMB-DENR, 2015).

turbance. Transect lines were established along trails due to the gorge shape of the mountain.

Sampling site 1 is a mixed dipterocarp forest with coordinates of $8^{\circ} 56.820^{\prime} \mathrm{N}, 124^{\circ} 52.042^{\prime} \mathrm{E}$. Its elevation ranges from 415-465 meters above sea level. The site has a mountainous slope and secondary vegetation type. Sunlight cannot easily penetrate through the ground due to the presence of high density of emergent and canopy trees. Emergent trees were Shorea sp. whereas canopy trees include Shorea negrosensis, S. contorta, Pterocarpus indicus, Swietenia mahogany, Dracontomelon dao, Artocarpus sericicarpus, and Ficus gul. Understory plants include the family Arecaceae, Costus igneus, and Caryota mitis. Most of the ground cover plants were Schismatoglottis calyptrata and ferns. Leaf litter depth measures about $2 \mathrm{~cm}$. The covering canopy trees have epiphytes such as ferns and vines coiling in their trunks. Orchids were also observed. Site 1 has a clay soil where exposed rocks and few fallen logs were present which may have been caused by a storm. A freshwater stream was located $100 \mathrm{~m}$ away. Its distance to anthropogenic clearing was $450 \mathrm{~m}$. Rubber plantation was near the area. Site 1 is where the main access is located which serves as the initial pathway in accessing the freshwater stream and thus high disturbance, mainly human-made, can be observed in the site.

Sampling site 2 is a riparian forest with coordinates of $8^{\circ} 56.834^{\prime} \mathrm{N}$ and $124^{\circ} 52.124^{\prime} \mathrm{E}$. Its elevation ranged from $350-450 \mathrm{~m}$ a.s.l. The site has an undulating slope and covered with secondary vegetation. A freshwater stream with shallow pools of water serves as a faunal corridor, connecting Sites 1 and 3. The site was dry, revealing large rocks due to the diversion of water for the water system of the people in the locality. Rocks were mainly covered with Bryophyta sp., especially near pools of water. The emergent tree was Shorea sp. while canopy trees were Dracontomelon dao, Bosscheria minahassae, and Artocarpus odoratissimus. The canopy epiphytes present include moss, vines, and ferns. Fruit-bearing tree taxa include Lansium parasiticum, Averrhoa carambola, and Artocarpus odoratissimus. Ferns, grasses, and sedges were rarely observed. Other plants include bamboo, Ficus benjamina, Pandanus yvanii, Cheilocostus speciosus, Poikilospermum suaveolens, Clerodendrum paniculatum, Alocasia princeps, and Aglaonema nitidum. Presence of Musa sp. was also noted. Forest floor near the stream is characterized by leaf litter, abundance of exposed rocks, humus, mosses, ferns, and fallen logs. Its 
distance to the anthropogenic clearing was about $500 \mathrm{~m}$. Intermediate disturbance was observed as indicated by the presence of plastic waste within the boundary of the freshwater stream. On-site disturbance also includes natural tree-fall.

Sampling site 3 is a mixed dipterocarp forest with neighboring agroecosystem. It has coordinates of $8^{\circ} 56.913^{\prime} \mathrm{N}, 124^{\circ} 52.109^{\prime} \mathrm{E}$ with elevation of 430-485 meters above sea level. The site has mountainous slope and secondary vegetation type. The emergent tree was Shorea sp. while canopy trees include Shorea negrosensis, S. contorta, $S$. polysperma, Dipterocarpus validus, and Ficus benjamina. Understory plants in the area include Diplodiscus paniculatus, family Arecaceae, Daemonorops ochrolepis, Calamus caryota, and Calamus mitis. Neighboring agroecosystem is partly used for growing coconuts, Cocos nucifera and coffee, Coffea sp. Forest floor is covered with moderate leaf litter measured to be about 1 centimeter in depth and few exposed rocks and fallen logs which are common microhabitats of grounddwelling spiders. Ground was wet, covered with plants like mosses, ferns, and Schismatoglottis calyptrata, the dominant ground cover plants present in this site. The distance of the site to anthropogenic clearing was about $1 \mathrm{~km}$. Site disturbances were human-made and natural tree-fall. Huge water pipes that extend to the community area for water source were present. Compared to Site 1, Site 3 is difficult to access due to the presence of enormous vegetation so very few anthropogenic disturbances were observed and thus it has low disturbance.

Collection, processing, identification of samples, and analysis

Sampling was conducted on July 18-27 2018 for 10 field days for a total of 186 work hours. Sampling starts every morning from 900 hours to 1300 hours, in the afternoon from 1400 hours to 1600 hours, and evening from 1800 hours to 2100 hours. Different sampling areas with different habitat structure, disturbance level, accessibility, and geographical position were established within the transect line. Collection in every point was extended up to 10 meters $(\mathrm{m})$ to the left and $10 \mathrm{~m}$ to the right of the transect line. For arboreal spiders, leaves, bushes, tree trunks, ferns, and grass lands were explored. Microhabitats of spiders such as fallen logs and leaf litter were examined for ground-dwelling spiders. Beat-netting and vial tapping methods were done to collect samples. Captured samples were placed in plastic cups and plastic bags to prevent escape of the motile spiders. Samples were then photographed. Voucher specimens were placed in vials with $90 \%$ ethanol. World Spider Catalog (WSC) created by world renowned arachnologist, Norman Platnick, and hosted by Natural History Museum of Bern was used to determine the general geographic region that a spider species is known to be distributed. For the spiders of the Philippines, the website insectoid.info and some published papers were used. Collection date, compartment name, and habitat were recorded on each vial. Specimens were identified by the third author.

Biodiversity indices which include species richness, relative abundance, Shanon-Weiner Diversity Index, and Pielou's evenness were calculated using Paleontological Statistics Software Package version 3.16 .

\section{RESULTS AND DISCUSSION}

\section{Species Composition}

A total of 108 species belonging to 17 families under 96 genera were collected during the sampling period in different sampling sites (Table 1). This number is higher compared to other areas in Mindanao, Philippines such as spiders recorded in Mt. Matutum, South Cotabato (Garciano et al., 2014) with 23 species under 19 genera and nine families; Mt. Pinukis, Zamboanga del Sur (Lalisan et al., 2015) with 99 species, 16 families, and 64 genera; and in Sacred Mountain in Marawi City (Juario et al., 2016) with 43 species belonging to 11 families under 31 genera. However, the present record is relatively low compared to the spider fauna in Marilog District, Davao City (Patiño et al., 2016) which consists of 171 species under 25 families. Species richness is significantly affected by flooding and vegetation cover within the surrounding areas (Galle \& Schweger, 2014). Rocha-Filho \& Rinaldi (2011) reported that different vegetation types with varying microhabitat structures affect spider distribution. Site 1 had 44 individuals. Site 2 had the 


\begin{tabular}{|c|c|c|c|c|c|}
\hline SPIDERS FAMILY AND SPECIES & SITE 1 & SITE 2 & SITE 3 & TOTAL & RA $(\%)$ \\
\hline \multicolumn{6}{|l|}{ ARANEIDAE (True Orb weavers) } \\
\hline Anepsion depressum $($ Thorell, 1877)^ & $\mathbf{0}$ & $\mathbf{0}$ & 19 & 1 & 0.549 \\
\hline Anepsion roeweri (Chrysanthus, 1961) & 19 & $\mathbf{0}$ & $\mathbf{0}$ & 1 & 0.549 \\
\hline Anepsion sp. & $\mathbf{1} \bigcirc \mathbf{S A}$ & $\mathbf{0}$ & $\mathbf{0}$ & 1 & 0.549 \\
\hline Araneus sp. & $\mathbf{0}$ & $\mathbf{0}$ & $1+$ & 1 & 0.549 \\
\hline Argiope aemula (Walckenaer, 1841) & $\mathbf{0}$ & $\mathbf{0}$ & $\mathbf{1 i}+$ & 1 & 0.549 \\
\hline Cyclosa sp. 1 & $\mathbf{0}$ & 19 & $\mathbf{0}$ & 1 & 0.549 \\
\hline Cyclosa sp. 2 & $\mathbf{0}$ & $\mathbf{0}$ & $2 \circ$ & 2 & 1.099 \\
\hline Cyrtophora sp. & $\mathbf{0}$ & $2+$ & $\mathbf{0}$ & 2 & 1.099 \\
\hline Eriovixia laglaizei (Simon, 1877) & $1+$ & $1+$ & $\mathbf{0}$ & 2 & 1.099 \\
\hline Eriovixia cf. laglaizei (Simon, 1877) & 1 & 1 & 19 & 3 & 1.648 \\
\hline Eriovixia sp. 1 & $\mathbf{0}$ & $\mathbf{0}$ & 2 古 & 2 & 1.10 \\
\hline Eriovixia sp. 2 & $\mathbf{0}$ & 19 & $\mathbf{0}$ & 1 & 0.549 \\
\hline Gasteracantha doriae (Simon, 1877) & $\mathbf{0}$ & $2+$ & 19 & 3 & 1.648 \\
\hline Hyposinga sp. & $\mathbf{0}$ & $\mathbf{0}$ & 19 & 1 & 0.549 \\
\hline Neoscona nautica (L. Koch, 1875) & $\mathbf{0}$ & 19 & $\mathbf{0}$ & 1 & 0.549 \\
\hline Neoscona cf. nautica (L. Koch, 1875) & $\mathbf{0}$ & $1 \mathbf{i}$ & $\mathbf{0}$ & 1 & 0.54 \\
\hline Neoscona punctigera (Doleschal, 1857) & $\mathbf{0}$ & $\mathbf{0}$ & 1 운 & 1 & 0.549 \\
\hline Neoscona sp. & $\mathbf{0}$ & 1 1운 & $\mathbf{0}$ & 1 & 0.549 \\
\hline Poltys sp. & $\mathbf{0}$ & $\mathbf{0}$ & $\mathbf{1} \mathbf{i}+$ & 1 & 0.549 \\
\hline Singa sp. & $\mathbf{0}$ & $\mathbf{0}$ & 19 & 1 & 0.549 \\
\hline Thelacantha brevispina (Doleschall, 1857) & $1+$ & $\mathbf{0}$ & $\mathbf{0}$ & 1 & 0.549 \\
\hline Verrucosa sp. & $\mathbf{0}$ & $\mathbf{1 i}, \mathbf{2}+$ & $\mathbf{1}+$ & 4 & 2.198 \\
\hline \multicolumn{6}{|l|}{ CLUBIONIDAE (Sac spiders) } \\
\hline Clubiona biembolata (Deeleman-Reinhold, 2001)^ & $\mathbf{1} \bigcirc \mathbf{S A}$ & $\mathbf{0}$ & $\mathbf{0}$ & 1 & 0.549 \\
\hline Clubiona corticalis (Walckenaer, 1802)^ & $\mathbf{1}+\mathbf{S A}$ & $\mathbf{0}$ & $\mathbf{0}$ & 1 & 0.549 \\
\hline Clubiona cf. japonicola (Bösenberg et Strand, 1906) & $\mathbf{0}$ & 19 & $\mathbf{0}$ & 1 & 0.549 \\
\hline Clubiona sp. & $\mathbf{0}$ & $1 \mathbf{i}$ & $\mathbf{0}$ & 1 & 0.549 \\
\hline Clubionidae immature & $\mathbf{0}$ & 19 & $\mathbf{0}$ & 1 & 0.549 \\
\hline Nusatidia camouflata (Deeleman-Reinhold, 2001)^ & 1 우 & 1 1우 & $\mathbf{0}$ & 2 & 1.099 \\
\hline Pristidia cf. longistila (Deeleman-Reinhold, 2001) & $\mathbf{0}$ & 1 1우 & $\mathbf{0}$ & 1 & 0.549 \\
\hline \multicolumn{6}{|l|}{ CTENIDAE (Wandering spiders) } \\
\hline Ctenus sarawakensis (F.O. Pickard-Cambridge, 1897) & $2 \hat{\jmath}$ & $2 \circ$ & 19 & 5 & 2.747 \\
\hline
\end{tabular}




\begin{tabular}{|c|c|c|c|c|c|}
\hline SPIDERS FAMILY AND SPECIES & SITE 1 & SITE 2 & SITE 3 & TOTAL & RA $(\%)$ \\
\hline Ctenus sp. & $\mathbf{0}$ & $\mathbf{0}$ & 1 1 & 1 & 0.549 \\
\hline \multicolumn{6}{|l|}{ DEINOPIDAE (Net-casting/Ogre face Spiders) } \\
\hline Deinopis sp. & 1 운 & $\mathbf{0}$ & $\mathbf{0}$ & 1 & 0.549 \\
\hline \multicolumn{6}{|l|}{ EUTICHURIDAE (Dark Sac Spiders) } \\
\hline Cheiracanthium sp. & $\mathbf{0}$ & $\mathbf{1}+$ & $\mathbf{0}$ & 1 & 0.549 \\
\hline \multicolumn{6}{|l|}{ LINYPHIIDAE (Sheet web weavers) } \\
\hline Plectembolus sp. & $\mathbf{0}$ & $\mathbf{1}$ ㅇ & $\mathbf{0}$ & 1 & 0.549 \\
\hline \multicolumn{6}{|l|}{ NEPHILIDAE (Golden Silk Orb-weavers) } \\
\hline Nephiladae immature & $\mathbf{0}$ & $\mathbf{0}$ & $1 \mathbf{i}$ & 1 & 0.549 \\
\hline Nephila pilipes (Fabricius, 1793) & $\mathbf{0}$ & $\mathbf{2} \odot \mathbf{i}, \mathbf{3}+\mathbf{S A}$ & $\mathbf{0}$ & 5 & 2.747 \\
\hline Herrenia sp. & $\mathbf{0}$ & $\mathbf{1} q \mathbf{S A}$ & $\mathbf{0}$ & 1 & 0.549 \\
\hline \multicolumn{6}{|l|}{ OXYOPIDAE (Lynx Spiders) } \\
\hline Hamadruas cf. hieroplyphica (Thorell, 1887) & 19 & $\mathbf{0}$ & $\mathbf{0}$ & 1 & 0.549 \\
\hline Oxyopes lineatipes (C.L. Koch, 1847) & $\mathbf{0}$ & $\mathbf{0}$ & $1 \jmath^{\lambda}$ & 1 & 0.549 \\
\hline \multicolumn{6}{|l|}{ PHOLCIDAE (Cellar spider/daddy long legs) } \\
\hline Calapnita deelemanae (Huber, 2011) & 19 & $\mathbf{0}$ & $\mathbf{0}$ & 1 & 0.549 \\
\hline Calapnita subphyllicola (Deeleman-Reinhold, 1986)* & $1 \hat{\jmath}$ & $\mathbf{0}$ & 2 & 3 & 1.648 \\
\hline Pholcus sp. 1 & 1 우 & $\mathbf{0}$ & $\mathbf{0}$ & 1 & 0.549 \\
\hline \multicolumn{6}{|l|}{ PISAURIDAE (Nursery web spider) } \\
\hline Hygropoda sp. & $\mathbf{0}$ & $1 \hat{\jmath}$ & $\mathbf{0}$ & 1 & 0.549 \\
\hline \multicolumn{6}{|l|}{ PSECHRIDAE (Lace-sheet weavers) } \\
\hline Psechrus sp. & $\mathbf{1} \partial^{\lambda}, \mathbf{1}+$ & 19 & $\mathbf{1 i}, 3+$ & 7 & 3.846 \\
\hline \multicolumn{6}{|l|}{ SALTICIDAE (Jumping spider) } \\
\hline Bavia aericeps (Simon 1877) & $\mathbf{0}$ & $\mathbf{0}$ & 19 & 1 & 0.549 \\
\hline Bavia sexpunctata (Doleschall 1859) & 19 & $\mathbf{0}$ & 19 & 2 & 1.099 \\
\hline Burmattus pococki (Thorell 1895)^ & 1 우 & $\mathbf{0}$ & $\mathbf{0}$ & 1 & 0.559 \\
\hline Cosmophasis sp. 1 & $10^{\lambda}$ & $\mathbf{0}$ & 19 & 2 & 1.099 \\
\hline Cosmophasis sp. 2 & $\mathbf{0}$ & $\mathbf{0}$ & $1+$ & 1 & 0.549 \\
\hline Evarcha sp. & $\mathbf{0}$ & $\mathbf{0}$ & $1{ }^{\lambda}$ & 1 & 0.549 \\
\hline Epeus sp. & 19 & $\mathbf{0}$ & $\mathbf{0}$ & 1 & 0.549 \\
\hline Hasarius adansoni (Audouin 1826) & $\mathbf{0}$ & $\mathbf{0}$ & $1{ }^{\lambda}$ & 1 & 0.549 \\
\hline Myrmarachne malayana (Edmunds et Proszynski 2003)^ & 0 & $2 \Uparrow$ & $\mathbf{1} \delta^{\lambda}, \mathbf{1}$ ㅇ & 4 & 2.198 \\
\hline Myrmaplata plataleoides (O. Pickard-Cambridge 1869)^ & 0 & 19 & 2 ? & 3 & 1.648 \\
\hline Omoedus sp. & 19 & $\mathbf{0}$ & $\mathbf{0}$ & 1 & 0.549 \\
\hline
\end{tabular}




\begin{tabular}{|c|c|c|c|c|c|}
\hline SPIDERS FAMILY AND SPECIES & SITE 1 & SITE 2 & SITE 3 & TOTAL & RA $(\%)$ \\
\hline Phintella versicolor (C.L. Koch 1846$)^{\wedge}$ & $\mathbf{0}$ & $\mathbf{1} \delta^{\lambda}, \mathbf{2} \propto$ & $\mathbf{0}$ & 3 & 1.648 \\
\hline Plexippus paykulli (Audoiun 1826) & 19 & $\mathbf{0}$ & $\mathbf{1} \jmath^{\lambda}, \mathbf{1} q$ & 3 & 1.648 \\
\hline Portia sp. & $\mathbf{0}$ & $1 \hat{\jmath}$ & $\mathbf{0}$ & 1 & 0.549 \\
\hline Pristobaeus jocosus $($ Simon 1902)^ & $\mathbf{0}$ & 1 우 & $\mathbf{0}$ & 1 & 0.549 \\
\hline Pseudeuophrys sp. & $\mathbf{0}$ & $\mathbf{0}$ & 19 & 1 & 0.549 \\
\hline Salticidae immature & $\mathbf{0}$ & $\mathbf{0}$ & $\mathbf{1 i}$ & 1 & 0.549 \\
\hline Telamonia dimidiata $($ Simon 1899)^ & $\mathbf{0}$ & $\mathbf{0}$ & 2 & 2 & 1.099 \\
\hline Telamonia cf. festiva (Thorell 1887) & 3 우 & $\mathbf{0}$ & 19 & 4 & 2.198 \\
\hline Thiania bhamoensis (Thorell 1877) & 19 & $\mathbf{0}$ & $\mathbf{0}$ & 1 & 0.549 \\
\hline Thyene $\mathrm{cf}$. manipisa (Barrion et Litsinger 1995) & 19 & $\mathbf{0}$ & $\mathbf{0}$ & 1 & 0.549 \\
\hline \multicolumn{6}{|l|}{ SPARASSIDAE (Giant Crab/Hunstman spiders) } \\
\hline Heteropoda boiei (Doleschall 1859)^^ & $\mathbf{0}$ & 19 & $\mathbf{0}$ & 1 & 0.549 \\
\hline Heteropoda cf. boiei (Doleschall 1859) & $\mathbf{0}$ & $\mathbf{0}$ & 19 & 1 & 0.549 \\
\hline Heteropoda davidbowie (Jager 2008)^ & $\mathbf{0}$ & 19 & $\mathbf{0}$ & 1 & 0.549 \\
\hline Heteropoda cf. davidbowie (Jager 2008) & $\mathbf{1} q \mathbf{S A}$ & $\mathbf{0}$ & $\mathbf{0}$ & 1 & 0.549 \\
\hline Heteropoda natans (Jager 2005)^ & $\mathbf{0}$ & 1 우 & $\mathbf{0}$ & 1 & 0.549 \\
\hline Heteropoda cf. natans (Jager 2005) & $\mathbf{0}$ & $\mathbf{0}$ & 19 & 1 & 0.549 \\
\hline Heteropoda tetrica $($ Thorell 1897)^ & $\mathbf{0}$ & 1 우 & $\mathbf{0}$ & 1 & 0.549 \\
\hline Heteropoda venatoria (Linnaeus 1767) & $\mathbf{1 i}+\mathbf{1}_{,} \mathbf{1}+$ & 19 & $\mathbf{0}$ & 3 & 1.648 \\
\hline Heteropoda sp. 1 & $\mathbf{1} \mathbf{i}$ 우 & $\mathbf{1} \delta^{\lambda}, \mathbf{1}$ ㅇ & $\mathbf{0}$ & 3 & 1.648 \\
\hline Heteropoda sp. 2 & $\mathbf{0}$ & 19 & $\mathbf{0}$ & 1 & 0.549 \\
\hline Heteropoda sp. 3 & $\mathbf{0}$ & $\mathbf{1} \delta^{\lambda} \mathbf{S A}$ & $\mathbf{0}$ & 1 & 0.549 \\
\hline Thelcticopis sp. 1 & $\mathbf{1}+$ & $\mathbf{0}$ & $\mathbf{0}$ & 1 & 0.549 \\
\hline Thelcticopis sp. 2 & $\mathbf{1}+$ & $\mathbf{0}$ & $\mathbf{0}$ & 1 & 0.549 \\
\hline Thelcticopis sp. 3 & $\mathbf{1} \subsetneq \mathbf{S A}$ & $\mathbf{0}$ & 19 & 2 & 1.099 \\
\hline Thelcticopis sp. 4 & $\mathbf{0}$ & $\mathbf{1} \overbrace{}^{\lambda} \mathbf{S A , 3}+$ & $\mathbf{0}$ & 4 & 2.198 \\
\hline Thelcticopis sp. 5 & $\mathbf{0}$ & $\mathbf{0}$ & 19 & 1 & 0.549 \\
\hline Thelcticopis sp. 6 & $\mathbf{0}$ & $\mathbf{0}$ & 1 우 & 1 & 0.549 \\
\hline \multicolumn{6}{|l|}{ TETRAGNATHIDAE (Long-jawed orb weaver) } \\
\hline Leucauge argentina (Hasselt 1882) & $\mathbf{0}$ & 3 & $\mathbf{0}$ & 3 & 1.648 \\
\hline Leucauge cf. argentina (Hasselt 1882) & 19 & $\mathbf{0}$ & $\mathbf{0}$ & 1 & 0.549 \\
\hline Leucauge cf. granulata (Walckenaer 1841) & $\mathbf{0}$ & 3 & $\mathbf{0}$ & 3 & 1.648 \\
\hline Leucauge sp. & $\mathbf{0}$ & $1+$ & $\mathbf{0}$ & 1 & 0.549 \\
\hline Opadometa fastigata (Simon 1877) & $\mathbf{1} \overbrace{}^{\top} \mathbf{S A}, 4+$ & 5 우 & 4 우 & 14 & 7.692 \\
\hline
\end{tabular}




\begin{tabular}{|c|c|c|c|c|c|}
\hline SPIDERS FAMILY AND SPECIES & SITE 1 & SITE 2 & SITE 3 & TOTAL & RA $(\%)$ \\
\hline Opadometa sp. & $1 \delta^{\lambda}$ & $\mathbf{0}$ & $\mathbf{0}$ & 1 & 0.549 \\
\hline Orsinome sp. & $\mathbf{0}$ & $\mathbf{0}$ & 19 & 1 & 0.549 \\
\hline Orsinome vethi (Hasselt 1882) & 0 & 19 & 0 & 1 & 0.549 \\
\hline Tetragnatha hasselti (Thorell 1890) & $\mathbf{0}$ & $\mathbf{0}$ & 19 & 1 & 0.549 \\
\hline Tetragnatha sp. 1 & $\mathbf{0}$ & $\mathbf{0}$ & $1+$ & 1 & 0.549 \\
\hline Tylorida ventralis (Thorell 1877) & $\mathbf{0}$ & $1+$ & $\mathbf{0}$ & 1 & 0.549 \\
\hline \multicolumn{6}{|l|}{ THERAPHOSIDAE (Tarantulas) } \\
\hline Phlogiellus baeri (Haupt et Schmidt 2004)* & $\mathbf{0}$ & $\mathbf{0}$ & $1 \bigcirc \mathbf{S A}, \mathbf{2 S A}$ & 3 & 1.648 \\
\hline \multicolumn{6}{|l|}{ THERIDIIDAE (Comb footed/Sheet line Spiders) } \\
\hline Argyrodes sp. & $\mathbf{0}$ & $\mathbf{0}$ & $\mathbf{1 i}$ & 1 & 0.549 \\
\hline Latrodectus sp. & $\mathbf{0}$ & $1+$ & $1+$ & 2 & 1.099 \\
\hline Parasteatoda sp. 1 & $\mathbf{0}$ & 19 & $1+$ & 2 & 1.099 \\
\hline Parasteatoda sp. 2 & $\mathbf{0}$ & $1+$ & $\mathbf{1} \bigcirc \mathbf{S A}$ & 2 & 1.099 \\
\hline Parasteatoda sp. 3 & 0 & 19 & $\mathbf{0}$ & 1 & 0.549 \\
\hline Parasteatoda sp. 4 & $\mathbf{0}$ & $\mathbf{1}+$ & $\mathbf{0}$ & 1 & 0.549 \\
\hline Phoroncidia sp. & $\mathbf{0}$ & $1+$ & $\mathbf{0}$ & 1 & 0.549 \\
\hline Steatoda sp. & 1 우 & $\mathbf{0}$ & $\mathbf{0}$ & 1 & 0.549 \\
\hline Theridion sp. 1 & $\mathbf{0}$ & $\mathbf{0}$ & $\mathbf{1}+\mathbf{S A} \mathbf{1}, 1^{\prime}$ & 2 & 1.10 \\
\hline Theridion sp. 2 & $\mathbf{0}$ & $1 \mathbf{i}$ & $\mathbf{0}$ & 1 & 0.549 \\
\hline Theridula sp. & $\mathbf{0}$ & $\mathbf{1}+\mathbf{S A}$ & $\mathbf{0}$ & 1 & 0.549 \\
\hline \multicolumn{6}{|l|}{ THOMISIDAE (Crab spiders) } \\
\hline Borboropactus sp. & $\mathbf{0}$ & 19 & $\mathbf{0}$ & 1 & 0.549 \\
\hline Misumena sp. & $\mathbf{0}$ & $\mathbf{0}$ & $\mathbf{1}+$ & 1 & 0.549 \\
\hline Thomisus callidus (Thorell 1890)^ & $1+$ & $\mathbf{0}$ & $\mathbf{0}$ & 1 & 0.549 \\
\hline Total no. of Individuals & 44 & 76 & 63 & 182 & \\
\hline Total no. of Species & 35 & 52 & 47 & 108 & \\
\hline Total no. of Genera & 26 & 33 & 37 & 96 & \\
\hline Total no. of Families & 12 & 13 & 12 & 17 & \\
\hline Total no. of Males & 9 & 7 & 5 & 21 & \\
\hline Total no. of Females & 34 & 62 & 52 & 149 & \\
\hline Total no. of Unclassified & 1 & 5 & 6 & 12 & \\
\hline
\end{tabular}

Table 1. Species richness and relative abundance of spiders in different sampling sites. Legend: Site $1=$ Mixed Dipterocarp

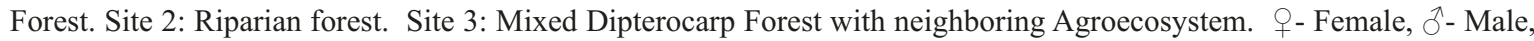
UC- unclassified, A-adult, SA- sub-adult, i- immature, RA (\%)- Relative Abundance, ${ }^{\wedge}$-New record * Philippine endemic. 
most abundance (74 individuals), whereas site 3 had 63 individuals. Site 1 had the least number of species (35 species), while Site 2 had the highest species richness (49 species).

Tsai et al. (2006) reported that the spatial structure of the environment influences spider habitat preferences. This could explain the high spider species richness observed in both Sites 2 and 3 where vegetation seems more diverse due to the availability of freshwater stream in site 2 providing resources such as habitat and potential preys for spiders. In Site 3, the presence of neighboring agroecosystem provides the spiders an additional habitat. As the vegetation matures, becoming denser and stratified, more species and families of spiders are present (Lowrie, 1948). Spiders relocate webs in response to web destruction and rebuild them in sites where enough stable structure is provided (Hodge, 1988) and thus, it may explain why the neighboring site, Site 1 , is more diverse.

Opadometa fastigata of Tetragnithidae emerged to be the most abundant spider species making up $7.692 \%$ of the total species collected including the fact that it is the most observed species during the sampling. It was evenly distributed in the sites.

Fifteen spiders were found to be new record species in the Philippines based on the World Spider Catalog (World Spider Catalog, 2018) and research studies. New records include Anepsion depressum (Thorell, 1877), Clubiona biembolata (DeelemanReinhold, 2001), Clubiona corticalis (Walckenaer, 1802), Nusatidia camouflata (Deeleman-Reinhold, 2001), Burmattus pococki (Thorell, 1895), Myrmarachne malayana (Edmunds \& Proszynski, 2003), Myrmaplata plataleoides (O. Pickard-Cambridge, 1869), Phintella versicolor (C.L. Koch, 1846), Pristobaeus jocosus (Simon, 1902), Telamonia dimidiata (Simon, 1899), Heteropoda boiei (Doleschall, 1859), Heteropoda davidbowie (Jager, 2008), Heteropoda natans (Jager, 2005), Heteropoda tetrica (Thorell, 1897), and Thomisus callidus (Thorell, 1890). So far, none of the species reported is classified as threatened in the International Union for Conservation of Nature red list of threatened species (IUCN, 2018). Two of the spiders are Philippine endemic based on the World Spider Catalog (World Spider Catalog, 2018). They are the Calapnita subphyllicola (Deeleman-Reinhold, 1986) and Phlogiellus baeri (Haupt \& Schmidt, 2004).

\section{Abundance and species richness of spider families}

In terms of relative abundance, Table 2 shows that the major families are Salticidae (19.78\%), Araneidae (18.13\%), Tetragnathidae (15.39\%), and Sparassidae (13.74\%). Family Salticidae comprised most of the overall population. It dominated Sites 1 (25\%) and 3 (26.98\%). According to LimaPeres et al. (2014), family Salticidae is the third most abundant family of spiders. Most of the spiders under this family were widely distributed in Site 3 with secondary growth and adjacent agroecosystem and thus providing a range of microhabitats. They occur in many microhabitats from under or below leaf litter up into the canopy (Richman et al., 2005). In Site 2, both families Araneidae $(18.42 \%)$ and Tetragnathidae $(18.42 \%)$ are the most abundant. Family Aranaeidae (18.13\%), the orb weavers, ranked second in terms of overall population. The spiders of this family are evenly distributed both in Sites 3 and 2. According to Dacanay et al. (2014), Araneidae prefers locations that are highly influenced by the presence of vegetation and even near water systems, shaded vegetation,

\begin{tabular}{|lcccc|}
\hline & \multicolumn{4}{c|}{ Relative Abundance (\%) } \\
\cline { 2 - 5 } Family & SITE 1 & SITE 2 & SITE 3 & Total \\
\hline Araneidae & 11.36 & 18.42 & 22.22 & 18.13 \\
Clubionidae & 6.82 & 6.58 & 0 & 4.396 \\
Ctenidae & 4.55 & 2.63 & 3.17 & 3.297 \\
Deinopidae & 2.27 & 0 & 0 & 0.549 \\
Eutichuridae & 0 & 1.32 & 0 & 0.549 \\
Linyphiidae & 0 & 1.32 & 0 & 0.549 \\
Nephilidae & 0 & 7.89 & 1.59 & 3.846 \\
Oxyopidae & 2.27 & 0 & 1.59 & 1.099 \\
Pholcidae & 6.82 & 0 & 3.17 & 2.747 \\
Pisauridae & 0 & 1.32 & 0 & 0.549 \\
Psechridae & 4.55 & 1.32 & 6.35 & 3.846 \\
Salticidae & 25 & 10.53 & 26.98 & 19.78 \\
Sparassidae & 15.91 & 17.11 & 7.94 & 13.736 \\
Tetragnathidae & 15.91 & 18.42 & 11.11 & 15.385 \\
Theraphosidae & 0 & 0 & 4.76 & 1.648 \\
Theridiidae & 2.27 & 10.53 & 9.52 & 8.242 \\
Thomisidae & 2.27 & 1.32 & 1.59 & 1.648 \\
\hline
\end{tabular}

Table 2. Relative abundance of spider families per site and overall study area. Site $1=$ Mixed Dipterocarp Forest. Site 2: Riparian forest. Site 3: Mixed Dipterocarp Forest with neighboring Agroecosystem. 
traces of logs, trunks of trees, and fallen trees. Araneidae spiders are common on the foliage or canopy of the plant vegetation which serves as anchors to stabilize their webs (Barrion et al., 2012). All sites have with secondary vegetation and thus provide high opportunity for the family araneidae to build orb-webs and also provide high number of prey. Site 2 is a riparian forest with freshwater stream that provides nutrition for potential prey for spiders and thus attracts spiders to build their webs near the site.

Figure 4 shows that family Araneidae ranked first in terms of species richness (22 species) while Salticidae ranked second (21 species). Per site, Salticidae dominates both the forested sites, Site 1 (9 species) and Site 3 (13 species). The foliage runners have 21 species from 16 genera. In Site 2, the riparian forest, family Sparassidae has the most species (9 species). Spider families with low species richness include: Ctenidae (2 species), Deinopidae (1 species), Eutichuridae (1 species), Linyphiidae (1 species), Nephilidae (3 species), Oxyopidae (2 species), Pholcidae (3 species), Pisauridae (1 species), Psechridae (1 species), Theraphosidae (1 species), and Thomisidae (3 species). Low species richness of these families is attributed to the rainy condition during sampling which makes it harder for the spiders to be seen. Species richness may vary across seasons. This might have also affected the total spider family richness of the Mimbilisan Protected Landscape

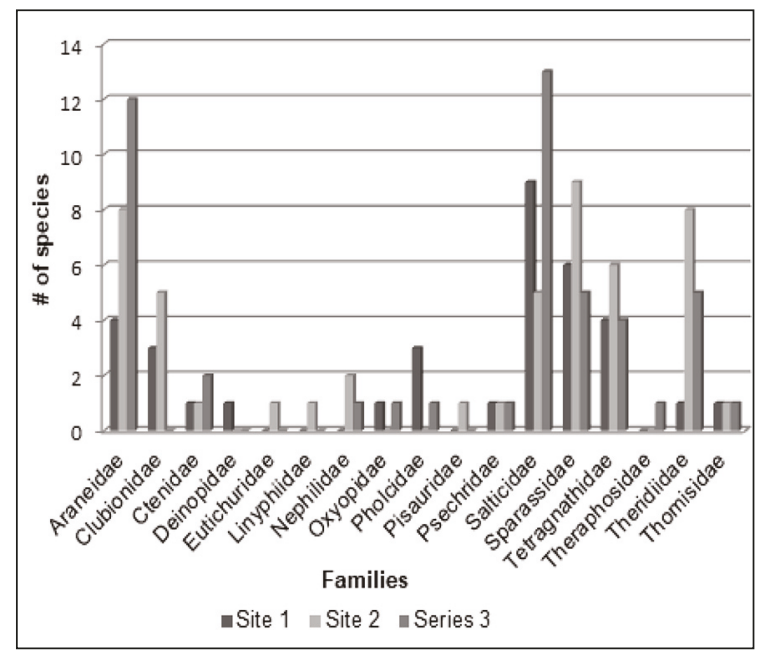

Figure 4. Number of species and family composition in each sampling site. since sampling was carried out during the month of July, a rainy month. Thus, species richness in the area may be greater than the actual data generated.

Eight families, namely Araneidae, Ctenidae, Psechridae, Salticidae, Sparassidae, Tetragnathidae, Theridiidae, and Thomisidae, were found to be present in all three sites indicating that they are well-adapted to these areas. Spider's ubiquity in different sites can be attributed to the good dispersal behavior of spiders. An act called ballooning allows spiders to travel from hundreds of meters to several kilometers (Bell et al., 2005). Four families, namely Clubionidae, Nephilidae, Oxyopidae, and Pholcidae, were observed in at most two sites. Spiders may have dispersed to another site due to the disturbances present which serve as their defense mechanism. One major key in surviving disturbances is through the ability of spiders to disperse (Moir et al., 2005). The families Deinopidae, Eutichuridae, Linyphiidae, Pisauridae, and Theraphosidae were only found at a single site but they are not considered as rare. Due to being cryptic or having a patchy distribution they may not have been adequately sampled (Patiño et al., 2016). It might also be due to the presence of a biotic and abiotic factors preferred by a species that cause it to be present only in a single site. According to Seyfulina (2005), both biotic and abiotic factors have different influences on the distribution of the different spider groups. It indicates that spatial variety of the vegetation may effect the spider diversity. For instance, Phlogiellus baeri can only be found in site 3 since in this site, light cannot easily penetrate due to high density of vegetation. The resulting low temperature and the presence of coconut husks are both preferred by $P$. baeri explaining its presence in this site.

\section{Age and Sex Structure}

Figure 5 shows the age and sex composition of recorded spiders. Collected spiders were a mixture of adults $(82.32 \%)$, sub-adults $(9.94 \%)$, and immatures $(7.73 \%)$. Among the adult spiders, females were dominant $(81.77 \%)$ and males are of low percentage $(12.15 \%)$. The same findings were observed in a study on Mt. Matutum, South Cotabato (Garciano et al., 2014), Mt. Pinukis, Zamboanga del Sur (Lalisan et al., 2015), and in Marilog Dis- 


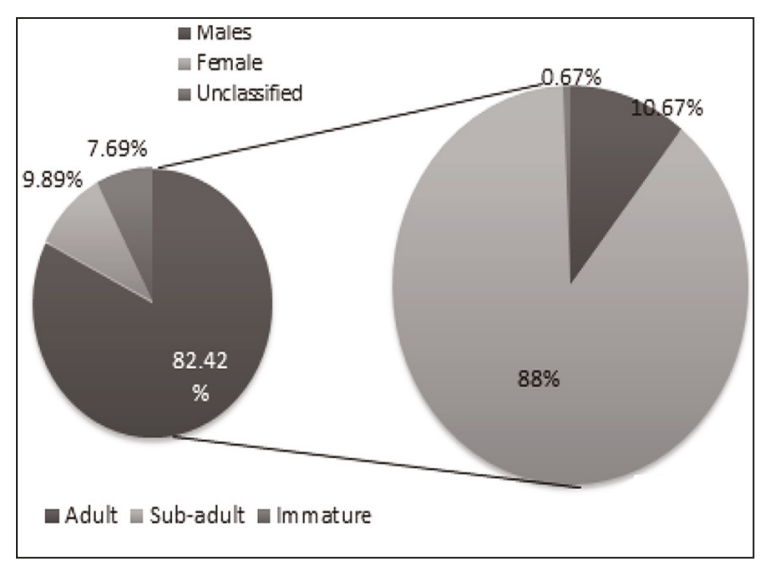

Figure 5. Age and sex percentage composition of collected individuals.

\begin{tabular}{|lcccc|}
\hline Indices & Site 1 & Site 2 & Site 3 & Total \\
\hline Species & 35 & 52 & 47 & 108 \\
Individuals & 44 & 76 & 63 & 182 \\
Shannon & 3.432 & 3.781 & 3.739 & 4.418 \\
Evenness & 0.8838 & 0.8437 & 0.8946 & 0.7676 \\
\hline
\end{tabular}

Table 3. Biodiversity indices of the three sampling sites.

trict, Davao City (Patiño et al., 2016). However, findings differed with the study in Rajah Sikatuna Protected Landscape, Bohol (Quiñones et al., 2016), where males dominated the area. Presence of dominant female spiders may be due to their morphological feature where male spiders are smaller (Wegner, 2011) and thus hard to be detected. Cannibalism behavior of female spider after mating is another factor where it is most widely observed in spiders (Elgar, 1992). Fatal encounter of males with potential predators during mate-searching is often ascribed to abundance of female spiders (Gaskett et al., 2004). Considering the fact that male spiders reach maturity faster than females, Romero \& Vasconsellos-Neto (2005) observed that female spiders are more frequently observed during adult and sub-adult stages while male spiders are frequent during the juvenile stage. High number of collected adults were observed since female spiders oviposit throughout the entire year (NietoCastañeda et al., 2012). Female spiders typically have larger abdomens than males. The epigynum that can only be found in female spiders lies near the epigastric furrow and bears the openings to the seminal receptacles while the male reproductive system of spiders has a pair of coiled tubular testes in the opisthosoma, which lead to a common sperm duct that opens into the epigastric furrow (Foelix, 2011). According to Wegner (2011) males of some families have the first pair of legs longer and/or more stocky and hairy in proportion to their size. Males have species-unique pedipalps with enlarged tips serving as sex organ (Brown \& Merchant, 2015).

\section{Biodiversity Indices}

Considering the importance of spiders in controlling insect pests and as bio-indicators, serious efforts are required in understanding their diversity (Umarani \& Umamaheswari, 2013). Table 3 shows the biodiversity indices in the three sampling sites of Mimbilisan Protected Landscape, Misamis Oriental. High diversity and even species distribution were observed in all sites. Site 2 had the most abundant spiders with 76 individuals comprising 52 species. Site 3 had 63 individuals in 47 species. Site 1 had the least abundance of 44 individuals with 35 species. A riparian forest serves as a faunal corridor, connecting adjacent ecosystems (Raizer et al., 2005). Site 2 serves as the transition zone between Sites 1 and 3. Edge effect hypothesis states that species richness increases at the border between different habitats (Odum, 1971) and thus, Site 2 has the highest species richness. Presence of the stream in Site 2 provides nutrients to nearby vegetation allowing it to grow enormously which then provides adequate habitat for the spider fauna particularly for the orb weavers.

According to Murcia (1995), the edges lead to variations in plant physiological response, vegetation structure, and forest species composition. The stream also attracts potential prey for the spiders. Site 3 was second in terms of species richness due to the presence of cultivated crops introduced in the area. The physical structure and species composition of vegetation define diversity of species and abundance through habitat availability (Malumbres-Olarte et al., 2013). This indicates that Site 2 vegetation structure is favorable to spi- 
ders. Site 1 with the highly disturbed vegetation had the lowest species diversity compared to the other sites because it serves as the main port in accessing the stream near Site 2. Moreover, Site 1 was the most accessible and visited site with higher disturbance to potential prey and the spiders themselves therefore decreasing spider richness and abundance. Low species richness is attributed to disturbed sites (Maya-Morales et al., 2012). As disturbance increases, the spider species richness decreases (Pinkus et al., 2006). Dacanay et al. (2014) reported low spider abundance and richness in very disturbed areas. Following Pielou's evenness index, all three sampling sites were found to be evenly distributed, although Site 2 got the lowest value compared to the two sites, which means that a species dominates the area. In this case, it was dominated by the species Opadometa fastigata, the most abundant species in Mimbilisan Protected Landscape. In addition, although Site 2 had the highest species richness and species diversity, Site 3 still has the highest evenness. Changes in ecological gradients due to human activities influence spider distribution and alter the community's composition (Uetz, 1976). Even though the different sites vary in biodiversity indices, the overall diversity of Mimbilisan Protected landscape is relatively high $\left(\mathrm{H}^{\prime}=4.36\right)$. Typically, values of Shannon-Wiener diversity index generally ranged from 1 to 3 which means that the diversity is moderate, low diversity if the index value is below 1, and high diversity if the index value is greater than 3 (Richardson, 1977). The value of H' increases as species richness and evenness increase.

\section{Guild Structure}

Guild structure of spiders is useful in studying ecology in describing diversity in communities (Freitas et al., 2013). The presence of this guild may be explained by the type of vegetation in the area which could provide adequate space of varying extent for building webs. Figure 4 shows the different guilds present in Mimbilisan Protected Landscape. The most dominant guild is the orb weavers comprising $37 \%$ of the distribution in the area. This guild is composed of families Araneidae and Tetragnathidae which were mostly collected in forest vegetation and bushes near the riparian for- est, mostly in sites 3 and 2, respectively, which provided wider expanse for web building such as building web between branches/stems of plants. The same observation was obtained in the Philippines by Patiño et al. (2016) in Marilog District, Davao City and Juario et al. (2016) in Sacred Mountain in Marawi City and in China by Barrion et al. (2012) in their study in the rice agricultural landscape of Hainan Island,. Garciano et al. (2014) found the orb weavers to be the most abundant comprising $61 \%$ of their total collected specimens. They were mostly found in shrubs, best for anchoring their webs. Richardson \& Hanks (2009) reported that the diversity of orb weavers is influenced by the floral community species composition. In this study (Fig. 6), web-building spiders are expected to be abundant because of the existence of bushes in the forested areas. Furthermore, since the forest is a secondary vegetation it provides more opportunity for the orb-weavers to build their webs around. The differences in web support structures brought about by the differences in microhabitats also affect spider density (Balfour \& Lypstra, 1998). Foliage runners formed the next dominant guild $(26 \%)$ in Sites 1 and 2 and the dominant guild in Site 3 which were commonly found above or beneath leaves. The spatial complexity of the leaf litter facilitates the existence of several species because it provides high surface

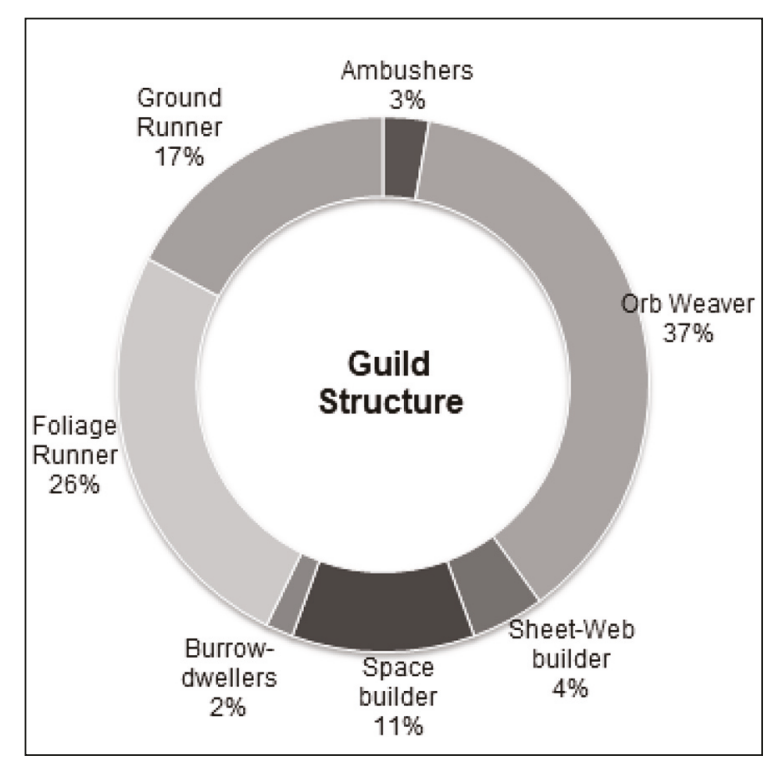

Figure 6. Percentage distribution of the different spider guilds at Mimbilisan Protected Landscape. 
area and foraging spaces within the leaves (Uetz, 1991). Most of the vegetation in the forest consisted of high surface leaves and thus provide more opportunity for the foliage runners. The most abundant ground vegetation was Schismatoglottis calyptrata locally called "dalili" which has high surface area. Ground runners (Ctenidae and Sparassidae) have $17 \%$ of the total relative abundance. Forest areas have leaf litter and provide opportunity for the ground runners. Space builders (Theridiidae and Pholcidae) have $11 \%$ relative abundance while sheet web weavers (Linyphiidae and Psechridae) have 4\%. Branches/stem of plants and rocks provide these space builders and sheet web weavers spaces/areas to anchor their webs. Ambushers (Deinopidae, Thomisidae and Pisauridae) have 3\% and burrow-dwellers (Theraphosidae) have $2 \%$ of the guild distribution. Mosses, humus, cover plants, and rocks on forest floor provide habitats for ambushers and burrow dwellers. In addition, according to Freitas et al. (2013), the dry climate and exposure to sunlight favor nocturnal ground hunters and runners.

\section{Spider Microhabitats}

Mimbilisan Protected landscape provides a variety of possible microhabitats for the spider fauna. Microhabitats include the branches/stem of plants, leaf surfaces/foliage, Schismatoglottis calyptrata locally called "dalili", forest floor, rocks, leaf litter, coconut husk, and fallen logs. The branches/stem of plants were used by spiders to anchor their webs and most of the jumping spiders were found hiding on or under leaf surfaces/foliage. Schismatoglottis calyptrata was the most observed ground vegetation providing a high surface area for the foliage runners. Mosses, humus, rocks, and cover plants on the forest floor provide opportunity for ambushers and burrowing spiders to hide on. Rocks serve as microhabitat for the ground dwelling spiders and some orb weavers. Leaf litter provides the ground dwelling spiders a microhabitat. Coconut husks serve as microhabitat for Phlogiellus baeri and it is here where Phlogiellus baeri can only be found. Some of the spiders such as the burrowing spiders were found on fallen logs. It seems that Site 1 with high disturbance and low diversity provides high number of microhabitats for the spiders. Foliage, stems, and fallen logs were found in all sites. Leaf litter and forest floor serve as the general microhabitat for ground-dwelling and burrowing spiders. Schismatoglottis calyptrata that was only found in forested area greatly provides microhabitat for spiders especially for leaf-dwelling spiders. In riparian forest, rocks are the microhabitat for both ground-dwelling and orb-weaver spiders. Lastly, in agro-ecosystem part of Site 3, coconut husk provides microhabitat for numerous Phlogiellus baeri.

Table 4 shows the different species of spiders documented with their respective microhabitats. Studies of relationships between spiders and the structure of habitats have shown that spiders use structures in their environment as cues to habitat quality, architectural foundations for prey-catching webs, and as vibration-conducting and monitoring surfaces in communication and prey capture (Uetz, 1991). The most utilized microhabitats by the spiders are between branches/stem of plants and leaf surfaces/foliage. This explains why the orbweavers and foliage runners were the most abundant guilds in the area to which the families Araneidae and Salticidae, the most abundant families with high species richness, belong, respectively. Possible factors that affect microhabitat selection include prey availability, leaf toxicity, and suitability of leaf structure for web attachment. According to Huber \& Schutte (2009), underlying mechanism is difficult to resolve due to the presence of factors influencing the spider's microhabitat choice.

\section{CONCLUSIONS}

Mimbilisan Protected Landscape has a relatively high species richness and high overall diversity of spiders. One-hundred eight species of spiders across the sampling sites were evenly distributed. Fifteen spider species are new record to the Philippines. Two spider species are Philippine endemic. About $82.32 \%$ of spiders are adult and mostly female $(81.77 \%)$. There were 17 families recorded in which Salticidae was the most abundant family. In terms of species richness, family Araneidae ranked first (22 species) and Salticidae was close behind (21 species). Of the seven guilds recorded, orb weavers were the most distributed, 


\begin{tabular}{|c|c|}
\hline Spider species & Microhabitat \\
\hline \multicolumn{2}{|l|}{ Araneidae } \\
\hline Anepsion depressum & $\begin{array}{l}\text { Schismatoglottis calyptrata (locally called } \\
\text { "dalili") leaf surface }\end{array}$ \\
\hline Anepsion roeweri & Schismatoglottis calyptrataleaf surface \\
\hline Anepsion sp. & On the web between branches/stem of plants \\
\hline Araneus sp. & On the web between branches/stem of plants \\
\hline Argiope aemula & On the web between branches/stem of plants \\
\hline Cyclosa sp. 1 & On the web between branches/stem of plants \\
\hline Cyclosa sp. 2 & $\begin{array}{l}\text { Schismatoglottis calyptrata locally leaf } \\
\text { surface, Leaf surfaces/foliage }\end{array}$ \\
\hline Cyrtophora sp. & $\begin{array}{l}\text { Leaf surfaces/foliage, On the web between } \\
\text { branches/stem of plants }\end{array}$ \\
\hline Eriovixia laglaizei & Leaf surfaces/foliage \\
\hline Eriovixia of. laglaizei & Leaf surfaces/foliage \\
\hline Eriovixia sp. 1 & On the web between branches/stem of plants \\
\hline Eriovixia sp. 2 & Leaf surfaces/foliage \\
\hline Gasteracantha doriae & On the web between branches/stem of plants \\
\hline Hyposinga sp. & Forest floor \\
\hline Neoscona cf. nautica & On the web between branches/stem of plants \\
\hline Neoscona nautica & Leaf surfaces/foliage \\
\hline Neoscona punctigera & On the web between branches/stem of plants \\
\hline Neoscona sp. & On the web between branches/stem of plants \\
\hline Poltys sp. & On the web between branches/stem of plants \\
\hline Singa sp. & On the web between branches/stem of plants \\
\hline Thelacantha brevispina & Leaf surfaces/foliage \\
\hline Verrucosa sp. & $\begin{array}{l}\text { Leaf surfaces/foliage, On the web between } \\
\text { branches/stem of plants }\end{array}$ \\
\hline \multicolumn{2}{|l|}{ Clubionidae } \\
\hline Clubiona biembolata & On the web between branches/stem of plants \\
\hline Clubiona corticalis & Forest floor \\
\hline Chubiona cf. japonicola & Leaf surfaces/foliage \\
\hline Clubiona sp. & Leaf surfaces/foliage \\
\hline Clubionidae immature & On the web between branches/stem of plants \\
\hline Nusatidia camouflata & $\begin{array}{l}\text { Schismatoglottis calyptrata, On the web } \\
\text { between branches/stem of plants }\end{array}$ \\
\hline Pristidia longistila & On the web between branches/stem of plants \\
\hline \multicolumn{2}{|l|}{ Ctenidae } \\
\hline $\begin{array}{l}\text { Ctenus sarawakensis) } \\
\text { Ctenus } \mathrm{sp} .\end{array}$ & $\begin{array}{l}\text { Forest floor, Leaf litter, Fallen logs } \\
\text { Forest floor }\end{array}$ \\
\hline \multicolumn{2}{|l|}{ Deinopidae } \\
\hline Deinopis sp. & On the web between branches/stem of plants \\
\hline \multicolumn{2}{|l|}{ Eutichuridae } \\
\hline Cheiracanthium sp. & On the web between branches/stem of plants \\
\hline \multicolumn{2}{|l|}{ Linyphiidae } \\
\hline Plectembolus sp. & On the web between branches/stem of plants \\
\hline \multicolumn{2}{|r|}{ Din tiv w } \\
\hline Nephiladae immature & On the web between branches/stem of plants \\
\hline Nephila pilipes & $\begin{array}{l}\text { Leaf surfaces/foliage, On the web between } \\
\text { Branches/stem of plants }\end{array}$ \\
\hline Herrenia sp. & On the web between branches/stem of plants \\
\hline \multicolumn{2}{|r|}{ 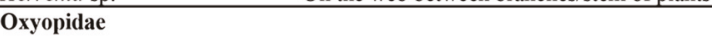 } \\
\hline $\begin{array}{l}\text { Hamadruas cf. hieroplyphica } \\
\text { Oxyopes lineatipes }\end{array}$ & $\begin{array}{l}\text { On the web between branches/stem of plants } \\
\text { Leaf surfaces/foliage }\end{array}$ \\
\hline \multicolumn{2}{|l|}{ Pholcidae } \\
\hline Calapnita deelemanae & $\begin{array}{l}\text { Schismatoglottis calyptrata, Leaf } \\
\text { surfaces/foliage }\end{array}$ \\
\hline Calapnita subphyllicola & $\begin{array}{l}\text { Schismatoglottis calyptrata, Leaf } \\
\text { surfaces/foliage, On the web between } \\
\text { branches/stem of plants }\end{array}$ \\
\hline Pholcus sp. 1 & Forest floor \\
\hline \multicolumn{2}{|l|}{ Pisauridae } \\
\hline Hygropoda sp. & Leaf surfaces/foliage \\
\hline \multicolumn{2}{|l|}{ Psechridae } \\
\hline Psechrus sp. & $\begin{array}{l}\text { On the web between branches/stem of } \\
\text { plants, Forest floor }\end{array}$ \\
\hline \multicolumn{2}{|l|}{ Salticidae } \\
\hline Bavia aericeps & $\begin{array}{l}\text { Schismatoglottis calyptrata, Leaf } \\
\text { surfaces/foliage }\end{array}$ \\
\hline Bavia sexpunctata & $\begin{array}{l}\text { Leaf surfaces/foliage, On the web between } \\
\text { Branches/stem of plants }\end{array}$ \\
\hline Burmattus pococki & Leaf surfaces/foliage \\
\hline Cosmophasis sp. 1 & $\begin{array}{l}\text { Leaf surfaces/foliage, On the web between } \\
\text { branches/stem of plants }\end{array}$ \\
\hline Cosmophasis sp. 2 & Leaf surfaces/foliage \\
\hline Evarcha sp. & Leaf surfaces/foliage \\
\hline Epeus sp. & On the web between branches/stem of plants \\
\hline Hasarius adansoni & Leaf surfaces/foliage \\
\hline
\end{tabular}

\begin{tabular}{|c|c|}
\hline Myrmarachne malayana & $\begin{array}{l}\text { On the web between branches/stem of } \\
\text { plants, Forest floor }\end{array}$ \\
\hline Myrmaplata plataleoides & $\begin{array}{l}\text { On the web between branches/stem of } \\
\text { plants, Leaf litter }\end{array}$ \\
\hline Phintella versicolor & $\begin{array}{l}\text { Leaf surfaces/foliage, On the web between } \\
\text { branches/stem of plants }\end{array}$ \\
\hline Plexippus paykulli & $\begin{array}{l}\text { Leaf surfaces/foliage, On the web between } \\
\text { branches/stem of plants }\end{array}$ \\
\hline Portia sp. & Leaf surfaces/foliage \\
\hline Pristobaeus jocosus & On the web between rocks \\
\hline Pseudeuophrys sp. & On the web between branches/stem of plants \\
\hline Salticidae immature & On the web between branches/stem of plants \\
\hline Telamonia dimidiata & Leaf surfaces/foliage \\
\hline Telamonia cf. festiva & $\begin{array}{l}\text { Leaf surfaces/foliage, On the web between } \\
\text { branches/stem of plants }\end{array}$ \\
\hline Thiania bhamoensis & Leaf litter \\
\hline Thyene $\mathrm{cf}$ manipisa & Leaf surfaces/foliage \\
\hline \multicolumn{2}{|l|}{ Sparassidae } \\
\hline Heteropoda boiei & Forest floor \\
\hline Heteropoda cf. boiei & Leaf litter \\
\hline Heteropoda davidbowie & On the web between branches/stem of plants \\
\hline Heteropoda $\mathrm{cf}$ davidbowie & Forest floor \\
\hline Heteropoda $\mathrm{cf}$ natans & Leaf surfaces/foliage \\
\hline Heteropoda natans & Leaf surfaces/foliage \\
\hline Heteropoda venatoria & $\begin{array}{l}\text { On the web between branches/stem of } \\
\text { plants, Forest floor }\end{array}$ \\
\hline Heteropoda sp. 1 & Forest floor, On the web between rocks \\
\hline Heteropoda sp. 2 & On the web between rocks \\
\hline Heteropoda sp. 3 & On the web between rocks \\
\hline Thelcticopis sp. 1 & Leaf litter \\
\hline Thelcticopis sp. 2 & Forest floor \\
\hline Thelcticopis sp. 3 & Forest floor, Leaf litter \\
\hline Thelcticopis sp. 4 & Forest floor, Leaf litter \\
\hline Thelcticopis sp. 5 & On the web between branches/stem of plants \\
\hline Thelcticopis sp. 6 & Forest floor \\
\hline \multicolumn{2}{|l|}{ Tetragnathidae } \\
\hline Leucauge argentina & $\begin{array}{l}\text { Leaf surfaces/foliage, On the web between } \\
\text { branches/stem of plants, On the web } \\
\text { between rocks }\end{array}$ \\
\hline Leucauge $\mathrm{cf}$ argentina & On the web between branches/stem of plants \\
\hline Leucange cf. granulata & $\begin{array}{l}\text { Leaf surfaces/foliage, On the web between } \\
\text { branches/stem of plants }\end{array}$ \\
\hline Leucauge sp. & Leaf surfaces/foliage \\
\hline Opadometa fastigata & $\begin{array}{l}\text { Leaf surfaces/foliage, On the web between } \\
\text { branches/stem of plants, On the web } \\
\text { between rocks }\end{array}$ \\
\hline Opadometa sp. & Leaf surfaces/foliage \\
\hline Orsinome sp. & $\begin{array}{l}\text { Leaf surfaces/foliage, On the web between } \\
\text { branches/stem of plants }\end{array}$ \\
\hline Orsinome vethi & Leaf surfaces/foliage \\
\hline Tetragnatha hasselti & $\begin{array}{l}\text { Schismatoglottis calyptrata, Leaf } \\
\text { surfaces/foliage }\end{array}$ \\
\hline Tetragnatha sp. 1 & $\begin{array}{l}\text { Schismatoglottis calyptrata, Leaf } \\
\text { surfaces/foliage }\end{array}$ \\
\hline Tylorida ventralis & Leaf surfaces/foliage \\
\hline \multicolumn{2}{|l|}{ Theraphosidae } \\
\hline Phlogiellus baeri & Coconut husk \\
\hline \multicolumn{2}{|l|}{ Theridiidae } \\
\hline Argyrodes sp. & Leaf surfaces/foliage \\
\hline Latrodectus $\mathrm{sp}$. & Leaf surfaces/foliage \\
\hline Parasteatoda sp. 1 & $\begin{array}{l}\text { Leaf surfaces/foliage, On the web between } \\
\text { branches/stem of plants }\end{array}$ \\
\hline Parasteatoda sp. 2 & $\begin{array}{l}\text { Leaf surfaces/foliage, On the web between } \\
\text { branches/stem of plants }\end{array}$ \\
\hline Parasteatoda sp. 3 & Leaf surfaces/foliage \\
\hline Parasteatoda sp. 4 & Leaf surfaces/foliage \\
\hline Phoroncidia sp. & $\begin{array}{l}\text { Schismatoglottis calyptrata leaf surface, } \\
\text { Leaf surfaces/foliage }\end{array}$ \\
\hline Steatoda sp. & On the web between branches/stem of plants \\
\hline Theridion sp. 1 & $\begin{array}{l}\text { Leaf surfaces/foliage, On the web between } \\
\text { branches/stem of plants }\end{array}$ \\
\hline Theridion & On the web between branches/stem of plants \\
\hline Theridula & Leaf surfaces/foliage \\
\hline \multicolumn{2}{|l|}{ Thomisidae } \\
\hline Borboropactus sp. & On the web between branches/stem of plants \\
\hline Misumena sp. & On the web between branches/stem of plants \\
\hline Thomisus callidus & On the web between branches/stem of plants \\
\hline
\end{tabular}

Table 4. Microhabitats used by the spiders in Mimbilisan Protected Landscape. 
being found in all sites. Opadometa fastigata, an orb-weaver, appears to be the most widely distributed species. Microhabitats were mostly branches/stems of plants and leaf surface/foliage. Results indicate that Mimbilisan Protected landscape is a highly diversified area which indicates a healthy ecosystem. Habitat structure, availability of microhabitat, and habitat disturbances appear to influence the diversity, distribution, and abundance of the spider species.

\section{ACKNOWLEDGEMENTS}

We want to thank the funding support of the Office of the Vice Chancellor for Research and Extension (OVCRE), MSU-Iligan Institute of Technology (MSU-IIT) through the Premier Research Institute of Science and Mathematics (PRISM); the logistical support of Protected Area Management Board (PAMB) of Mt. Mimbilisan Protected Landscape; and CENRO-DENR of Gingoog City.

\section{REFERENCES}

Balfour R.A. \& Lypstra A.L., 1998. The influence of habitat structure on spider density in a no-till soybean agroecosystem. The Journal of Arachnology, 26: 221-226. Retrieved on February 14, 2018. http://www.americanarachnology.org/

Barrion A.T. \& Litsinger J.A., 1995. Riceland spiders of south and southeast Asia. International Rice Research Institute. Manila, Philippines, 716 pages. http://agris. fao.org/agris-search/index.do

Barrion A.T., 2001. Spiders: natural biological control agents against insect pests in Philippine rice fields. Transactions of the National Academy of Science and Technology, 23: 121-130. http://agris.fao.org/agrissearch/home

Barrion A.T., Villareal S.S., Catindig J., Cai D., Yuan Q.H. \& Heong K.L., 2012.The spider fauna in the rice agricultural landscape of Hainan Island, China: Composition, abundance and feeding structure. Asia Life Sciences, 21: 625-651. http://www.sersc.org/ journals/ALS/

Bell J.R., Bohan D.A., Shaw E.M. \& Weyman G.S., 2005. Ballooning dispersal using silk: world fauna, phylogenies, genetics and models. Bulletin of entomological research, 95: 69-114. https://doi.org/10. 1079/ BER2004350
BMB-DENR, Biodiversity Management Bureau, 2015. Guidebook to Protected Areas of the Philippines. Biodiversity Management Bureau - Department of Environment and Natural Resources, Philippines. pp. 100

Brown W. \& Merchant M., 2015. Spiders. Texas A\&M AgriLife Extension Service. agrilife.org/ extensionento/files/2017/06/Spiders E408.pdf.

Cardoso P., 2012. Diversity and community assembly patterns of epigean vs. troglobiont spiders in the Iberian Peninsula. International Journal of Speleology, 41: 83-94. https://doi.org/10.5038/1827-806X. 41.1.9

Carvalho J.C., Cardoso P., Crespo L.C., Henriques S., Carvalho R. \& Gomes P., 2011. Biogeographic patterns of spiders in coastal dunes along a gradient of mediterraneity. Biodiversity and Conservation, 20: 873-894. https://doi.org/10.1007/s10531-011-0001-8

Chen K. \& Tso I., 2004. Spider Diversity on Orchid Island, Taiwan: A Comparison between Habitats Receiving Different Degrees of Human Disturbance. Zoological Studies, 43: 598-611. http://zoolstud. sinica.edu.tw

Clarke J.H., 2002. A dictionary of Practical Materia Medica (Vol. I, II \& III). B. Jain Publishers (P) Ltd., 2586 pp. https://www.bjainbooks.com/

Dacanay C.C., Barrion-Dupo A.A. \& Nuñeza O.M., 2014. Rapid assessment of spider fauna of Pulacan falls, Zamboanga Del Sur, Philippines. Biodiversity and Environmental Sciences, 5: 455-464. http:// www.innspub.net/journal/journal-of-biodiversityand-environmental-sciences-jbes/

Elgar M.A., 1992. Sexual cannibalism in spiders and other invertebrates. In: Elgar M.A. \& Crespi B.J. (Eds.), Cannibalism. Ecology and Evolution among Diverse Taxa: 128-155. Oxford University Press, Oxford, New York, Tokyo. http://arnqvist.org/

Enriquez C.M.D. \& Nuñeza O.M., 2014. Cave spiders in Mindanao, Philippines. Extreme Life, Biospeology and Astrobiology Bioflux, 6: 46-55. http://www. elba.bioflux.com.ro

Foelix R.F., 2011. Biology of spiders. Third Edition. Oxford University Press, New York, N.Y., 419 pp.

Freitas G.C.C., Brescovit A.D. \& Vasconcelos S.D., 2013. Spider diversity on the oceanic island of Fernando de Noronha, Brazil, and implications for species conservation. Journal of Insect Science, 13: 1-16. https://doi.org/10.1673/031.013.14801

Galle R. \& Schweger S., 2014. Habitat and landscape attributes influencing spider assemblages at lowland forest river valley (Hungary). North-Western Journal of Zoology, 10: 36-41. http://biozoojournals.ro/ nwjz/index.html

Garciano D.P., Nuñeza O.M. \& Barrion-Dupo A., 2014. Species richness of spiders in Mt. Matutum, South 
Cotabato, Philippines. Journal of Biodiversity and Environmental Sciences, 4: 214-224. http://www. innspub.net/journal/ journal-of- biodiversity-and-environmental-sciences-jbes/

Gaskett A.C., Herberstein M.E., Downes B.J. \& Elgar M.A., 2004. Changes in male-matechoice in a sexually cannibalistic orb-web spider (Araneae: Araneidae). Behaviour, 141: 1197-1210. http://www.jstor. org/stable/4536195

Haupt J. \& Schmidt G., 2004. Description of the male and illustration of the female receptacula of Yamia watasei Kishida, 1920 (Arachnida, Araneae, Theraphosidae, Selenocosmiinae). Spixiana. 27: 199-204. https://www. biodiversitylibrary.org/

Hinman M.B., Jones J.A. \& Lewis V.R., 2003. Synthetic spider silk: a modular fibre. Trend Biotech, 18: 374379. https://doi.org/10.1016/S0167-7799(00)014815

Hodge M., 1988. Factors influencing web site residence time of the orb weaving spider, Micrathena gracilis. Psyche, 94: 363-371. Texas A\&M University, 1-86.

Hodge S. \& Vink C.K., 2010. An evaluation of Lycosa hilaris as an indicator of organophosphorous insecticide contamination, New Zealand Plant Protection 53: 226-229. https://nzpps.org/

Hore U. \& Uniyal V.P., 2009. Diversity and Structure of Spider Assemblages in Terai Conservation Area. Saurashtra University, $250 \mathrm{pp}$. https://doi.org/10. 1636/CT07-53.1

Huber B.A. \& Schutte A., 2009. Preliminary Notes on Leaf-dwelling Metagonia spiders (Araneae: Pholcidae) in the Esquinas Rainforest near La Gamba, Costa Rica: Leaf-preference, mimesis, and web structure. Contributions to Natural History (Bern), 12: 681-697.

IUCN., 2018. The IUCN Red List of Threatened Species. Version 2017-3. <http://www. iucnredlist. org $>$. Downloaded on 14 April 2020.

Juario J., Nuñeza O.M. \& Dupo A.L., 2016. Species richness of spiders in Sacred Mountain, Marawi City, Philippines. Journal of Biodiversity and Environmental Sciences, 8: 86-94. http://www.innspub.net/

Lalisan J., Dupo A.L. \& Nuňeza O., 2015. Diversity of spiders along an elevational gradient in Mt.Pinukis, Zamboanga del Sur, Philippines. Journal of Biodiversity and Environmental Sciences, 7: 190201.http://www.innspub.net/journal/journal-ofbiodiversity-and-environmental-sciences-jbes/

Lima-Peres M.C., K.R. Benati A., Rodrigues S., Derade M.V.A., Guimarães T., Da Silva M., Brescovit A.D. \& Delabie J.H.C., 2014. Tree-fall gaps effects on spider (Araneae) assemblages in an Atlantic Forest landscape in Northeastern Brazil. Open Journal of Animals Science, 4: 118-133. http://www.scirp.org/ Index.aspx
Lowrie D.L., 1948. The ecological succession of spiders in the Chicago area dunes. Ecology, 29: 334-351. https://esajournals.onlinelibrary.wiley.com/

Mahalakshmi R. \& Jeyaparuathi S., 2014. Diversity of Spider Fauna in the Cotton Field of Thailakulam, Virudhunagar District, Tamil Nadu, India. The Journal of Zoology Studies, 1: 12-18. http://www.journalof zoology. com/

Malumbres-Olarte J., Vink CJ., Ross JG., Cruickshank RH. \& Paterson AM., 2013. The Role of Habitat Complexity on Spider Communities in Native Alpine Grasslands of New Zealand. Insect Conservation and Diversity, 6: 124-134. https://doi.org/10.1111/j.1752 $-4598.2012 .00195 . x$

Maphill, 2013. Retrieved on April 14, 2018. http://www. maphill.com/

Mathew M.J., Sudhikumar A.V. \& Joseph J., 2009. Natural history and bioecology. In: Sebastian P.A. \& Peter K.V. (Eds.), Spiders of India. pp. 40-63. Universities Press (India) Private Limited, 2009, Hyderabad India. http://books.google.com.ph/books? id=9o VHO3ZGx4C \& printsec $=$ frontcover\& source $=\mathrm{gbs}$ ge_summary_r\&cad $=0 \# \mathrm{v}=$ onepage $\& \mathrm{q} \& \mathrm{f}=$ false.

Maya-Morales J., Ibarra-Nuñez G., Leon-Cortes J.L. \& Infante F., 2012. Understory spider diversity in two remnants of Tropical Montane Cloud Forest in Chiapas, Mexico. Journal of Insect Conservation, 16: 2538. http://dx.doi. org/10.1007/s10841-011-9391-x.

Moir M.L., Brennan K.E.C., Koch J.M., Majer J.D. \& Fletcher M.J., 2005. Restoration of a 321 forest ecosystem: The effects of vegetation and dispersal capabilities on the reassembly of plant-322 dwelling arthropods. Forest Ecology and Management, 217: 294-306. https://doi.org/10.1016/j.foreco.2005.06. 012

Mondejar E. \& Nuñeza O.M., 2016. Microhabitats of Pholcid Spiders (Araneae: Pholcidae) in Mt. Kitanglad Agri-Ecological and Techno-Demo Center, Imbayao, Bukidnon, Philippines. Journal of Biodiversity and Environmental Sciences, 8: 44-52. http:// www. innspub.net/ journal/journal-of-biodiversityand-environmental-sciences-jbes/

Murcia C., 1995. Edge effects in fragmented forests: implications of conservation. Trends in Ecology and Evolution, 10: 58-62. https://doi.org/10.1016/S0169 $-5347(00) 88977-6$

Nieto-Castañeda I.G., Salgado-Ugarte I.H. \& JiménezJiménez M.L., 2012. The life cycle of a desert spider inferred from observed size frequency distribution. Acta Zoológica Mexicana, (n. s.), 28: 353-364. http://www1.inecol.edu.mx/azm/

Odum E.P., 1971. Fundamentals of ecology. Third edition. Saunders: Philadelphia, 574 pp.

Ong P.S., 2002. Current status and prospects of protected areas in the light of the Philippine biodiversity con- 
servation priorities. Proc. IUCN/WCPA-EA-4, Taipei Conference, March 18-23, 2002, Taiwan, 95-125.

Patiño S.C., Barrion-Dupo A.L. \& Nuñeza O., 2016. Rapid assessment of spider fauna in Marilog District, Davao City, Philippines. Journal of Biodiversity and Environmental Sciences, Vol. 8, No. 1, 95-109. http://www.innspub.net/journal/journal-of-biodiversity-and-environmental-sciences-jbes/

Pinkus M.A., Ibarra-Nuñez G., Parra-Tabla V., GarcíaBallinas J.A. \& Hénaut Y., 2006. Spider diversity in coffee plantations with different management in Southeast Mexico. Journal of Arachnology, 34: 104112. https:// doi.org/10.1636/M03-044.1

Puja K., 2014. Diversity of Spiders fauna from Sarangpuri Lake, Arvi, Vidarbha Region. International. Journal of Life Sciences, 2: 165-167. http://www. ijlsci.in/

Quiñones L.E., Barrion-Dupo A.L. \& Nuñeza O.M., 2016. Salticidae species richness in Rajah Sikatuna Protected Landscape (RSPL), Bohol, Philippines. ELBA Bioflux, 8: 18-26. http://www.elba.bioflux. com.ro/

Raizer J., Japyassu' H.F., Indicatti R.P. \& Brescovit A.D., 2005. Comunidade de Aranhas (Arachnida, Araneae) do Pantanal Norte (Mato Grosso, Brasil) e sua similaridade com a Araneofauna Amazonica. Biota Neotropica, 5(1a). https://doi.org/10.1590/ S1676-06032005000200011

Richardson J.L., 1977. Dimensions of Ecology. Williams \& Wilkins Co. Baltimore USA, 412 pp.

Richardson M.L. \& Hanks L.M., 2009. Effects of Grassland Succession on Communities of Orb-Weaving Spiders. Environmental Entomology, 38: 1595-1599. https://academic.oup.com/ee

Richman D.B., Edwards G.B. \& Cutler B. 2005. Salticidae. Spiders of North America: an identification manual. ( Ubick D., Paquin P., Cushing P.E. \& Roth V. (Eds.), American Arachnological Society, 205-216. http://www.americanarachnology.org/

Rocha-Filho L.C. \& Rinaldi I.M.P., 2011. Crab spiders (Araneae: Thomisidae) in flowering plants in a Brazilian "Cerrado" ecosystem. Brazilian Journal of Biology, 71: 359-364. Retrieved on April 14, 2018 http://dx doi.org/10.1590/S1519-698420110003000 04.

Romero G.Q. \& Vasconcellos-Neto J., 2005. Spatialdistribution and microhabitat preference of Psecas chapoda (Peckham \& Peckham) (Araneae, Salticidae). Journal of Arachnology, 33: 124-134. https:// doi.org/10.1636/M03-9

Royauté R. \& Buddle C.M., 2012., Colonization dynamics of agroecosystem spider assemblages after snowmelt in Quebec (Canada). The Journal of Arachnology, 40: 48-58. https://doi.org/10.1636/P1116.1
Seyfulina R.R., 2005. Microhabitat effect on spider distribution in winter wheat agroecosystem (Araneae). Acta Zoologica Bulgarica, 1: 161-172. http://www. european-arachnology.org/wdp/

Sharma S., 2014. A study on spiders as predators on the Agro Ecosystes. Munis Entomology \& Zoology, 9: 80-83. http://www.munisentzool.org/

Sorensen L.L., Coddington J.A. \& Schraff N., 2002. Inventorying and Estimating Subcanopy Spider Diversity Using Semiquantitative Sampling Methods in an Afromontane Forest. Environmental Entomology, 31: 319-330. https://doi.org/10.1603/0046-225X-31.2. 319

Thomas C.D., Cameron A., Green R.E., Bakkenes M., Beaumont L.J., Collingham Y.C., Erasmus B.F.N., De Siqueira M.F., Grainger A., Hannah L., Hughes L, Huntley B., van Jaarveld A.S., Midgley G.F., Miles L., Ortega-Huerta M.A., Townsend P.A., Philips O.L. \& Williams S.E., 2004. Extinction risk from climate change. Nature, 427: 145-148. https://doi.org/10. 1038/nature02121

Thorell T., 1877. Studi sui Ragni Malesi e Papuani. I. Ragni di Selebes raccolti nel 1874 dal Dott. O. Beccari. Annali del Museo Civico di Storia naturale di Genova, 10: 341-634.

Tsai Z.I., Huang P.S. \&Tso I.M., 2006. Habitat Management by Aboriginals Promotes High Spider Diversity on an Asian Tropical Island. Ecography, 29: 84-94. http://dx.doi.org/10.1111/j.2006.0906-7590. 04425.x

Uetz G.W., 1976. Gradient analysis of spider communities in a streamside forest. Oecologia, 22: 373-385. https://doi.org/10.1007/BF00345314

Uetz G.W., 1991. Habitat structure and spider foraging. In: Bell S.S., McCoy E.D. \& Mushinsky H.R. (Eds.), Habitat structure, The Physical arrangement of objects in space, 325-348. Chapman and Hall. https:// doi.org/10.1007/978-94-011-3076-9

Umarani S. \& Umamaheswari S., 2013. Diversity of spider fauna at different sites in Palani Hills Dindigul District, Tamil, Nadu, South India. International Journal of Advance Biological Research, 3: 535-539. http://www. journalijar.com/

Wankhade V.W., Manwar N.A., Rupwate A.A. \& Raut N.M., 2012. Diversity and abundance of spider fauna at different habitats of University of Pune, M.S. (India). Global Advanced Research Journal of Environmental Science and Toxicology, 1: 203-210. http ://garj.org/

Wegner G.S., 2011. Spider Identification Guide. BASF Corporation, Forham Park, N.J., 55 pp. https://www. basf.com

Wilder S.M., 2011. Spider Nutrition: An Integrative Perspective. Advances in Insect Physiology, 40: 87-136. http://agris.fao.org/ agris-search/index.do 
Workman T., 1896. Malaysian Spiders. Belfast, Part 2,3, World Spider Catalog., 2018. World Spider Catalog. Nat9-24. Retrieved on April 14, 2018. https://archive. org/details/Malaysianspider00Work ural History Museum Bern, online at http://wsc. nmbe.ch, version 19.0, https://doi.org 10.24436/2 